\title{
Homeroom Symposium and Calamity Response Level of Senior High School Learners
}

\author{
Elymar A. Pascual \\ elymarpascual@rocketmail.com \\ Department of Education, Nagcarlan District, Laguna, Philippines, 4002
}

\begin{abstract}
The second semester of the school year 2019 - 2020 was bombarded with different calamities and pandemic that hamper school days. This paper sought to determine the significant difference of calamity response level of senior high school learners of Talangan Integrated National High School, Nagcarlan, Laguna, Philippines, when measured across sex groups, family income status and academic performance. With the conduct of monthly homeroom symposium that dealt with non-academic topics such as reaching out to people, continuing life in the midst of adversities, and developing full potential as God's stewards, the researcher also measured the relationship of homeroom symposia application and calamity response level of learners. The writing of this research study revolved around the concept of a qualitative approach, in which data came from responses through survey questions provided to 32 Grade 11 learners through social media, in the midst of the quarantine period battling against COVID-19. The questionnaire has the following parts: learners' profile, homeroom symposium application, and calamity response level with 3 indicators: reaching out to people, continuous study at home in the midst of calamity, and maximizing time to do productive tasks. It was found out that there is a significant difference in calamity response level in terms of reaching out when checked across family income status. Those who have average family income tends to reach out more than those with below average and above average family income status. Also, it came out that there is a significant relationship between homeroom symposia application and calamity response level in terms of continuous study and maximizing time. Through homeroom symposium, learners' desire to continue studying at home and develop their potentials is sustained. Recommendations were given to classroom advisers, school heads, district supervisors and future researchers.
\end{abstract}

Keywords: homeroom; symposium; calamity; response; reaching out; study; maximize; time

\section{Introduction}

The second semester of school year 2019-2020 was filled with calamities, both natural and pandemic health occurrence. Philippines was hit by Typhoon Tisoy (international name Typhoon Kammuri) last December 2019, making four landfalls in Sorsogon, Masbate, Marinduque and Oriental Mindoro provinces. Bulkang Taal erupted in the afternoon of January 12, Sunday, and left the provice of Batangas and other nearby provinces affected by ashfalls. The Luzon Enhanced Community Quarantine was declared by President Duterte because of COVID-19 last March 15, and this was deemed to last until April 12. All of these hampered the school days of learners.

"The government activated the Response Cluster effective 03 December 2019, with the Local Government Units planning to conduct Rapid Damage Assessment and Needs Analysis (RDANA). The National Disaster Risk Reduction and Management Council (NDRRMC) maintains its BLUE alert 
status and declared that situation is still within government capacities in spite of the 4 Regions (IVA, $I V B, V$ and VII) that are still on RED alert." (AHA Centre Disaster Monitoring and Response System, 2019)

This typhoon alert was associated with the cancellation of classes from December 2, Monday, till December 4, Wednesday, in the province of Laguna, taking three days in the school calendar where learners are supposed to gain competencies from classroom teachings and activities.

"The eruption of Taal Volcano in Batangas, Philippines on January 12, 2020, was a phreatic eruption from its main crater that spewed ashes across Calabarzon, Metro, Manila, and some parts of Central Luzon and Ilocos Region, resulting to the suspension of classes, work schedules, and flights in the area." (Wikipedia, 2020)

This second natural calamity shocked many Pilipinos specifically in the CALABARZON area in the serene Sunday afternoon, when spectacle of mass ash formation was seen in the sky. The next day, for whole week, classes were suspended and learners need to stay at home and protect themselves from ashes.

"On March 16, 2020, Rodrigo Duterte declared the entire Luzon area in the Philippines under 'enhanced community quarantine,' which is effectively a total lockdown, restricting the movement of the population with exceptions, in response to the growing pandemic of COVID-19 in the country. Additional lockdown restrictions mandated the temporary closure of non-essential shops and businesses." (Wikipedia, 2020)

Lastly, on the last two months of school year, another calamity which is disease in nature broke the Philippine scenario, adding to the schools days where learners need to stay at home. How do learners respond during such calamities?

\subsection{Background of the Study}

In order to lead learners to greater heights, homeroom guidance program can provide information to teachers with regards to learners' strengths and weaknesses. The writings of Bennett shows how he wanted to have a change in public education system, starting from few teachers who would embrace challenges, and then affecting the school and the whole education itself. He wants teachers to "experience, understand and apply how to integrate a variety of instructional concepts, skills, tactics, and strategies in the design of more powerful learning environments...with a focus on literacy." (Bennett 1991). One way execute homeroom guidance program is through classroom symposium.

Table 1. Homeroom symposia done during second semester of school year 2019-2020

\begin{tabular}{|c|c|c|c|}
\hline Month & Topic & Activities & Calamity Response to Tap \\
\hline November & $\begin{array}{c}\text { Being Contented andSharing } \\
\text { Blessings to Others }\end{array}$ & $\begin{array}{c}\text { Breakfast symposium with } \\
\text { storytelling of the rich } \\
\text { family, and journal-writing }\end{array}$ & Reaching out to others \\
\hline December & $\begin{array}{c}\text { Godis Faithful; Be a Faithfull } \\
\text { Steward }\end{array}$ & $\begin{array}{c}\text { Breakfast symposium with } \\
\text { song analysis, and journal- } \\
\text { writing }\end{array}$ & Maximizing time \\
\hline January & $\begin{array}{c}\text { Continue Life; Godhas } \\
\text { Reas on for Everything }\end{array}$ & $\begin{array}{c}\text { Breakfast symposium with } \\
\text { one-on-one counseling } \\
\text { through index card } \\
\text { communication }\end{array}$ & Continuous study \\
\hline February & Being a Light to Others & $\begin{array}{c}\text { Breakfast symposium with } \\
\text { candle-lighting ceremony, } \\
\text { and journal-writing }\end{array}$ & Reaching out to others \\
\hline
\end{tabular}


At the outset of the second semester, the 40 learners from Grade 11 Vibrant composed of two academic tracks, namely Accountancy, Business and Management, and General Academic Strand, conducted classroom symposia as part of the homeroom guidance program of their adviser who is also the author of this study. The table in the previous page and the succeeding collage picture show the summary of the symposia done every month.

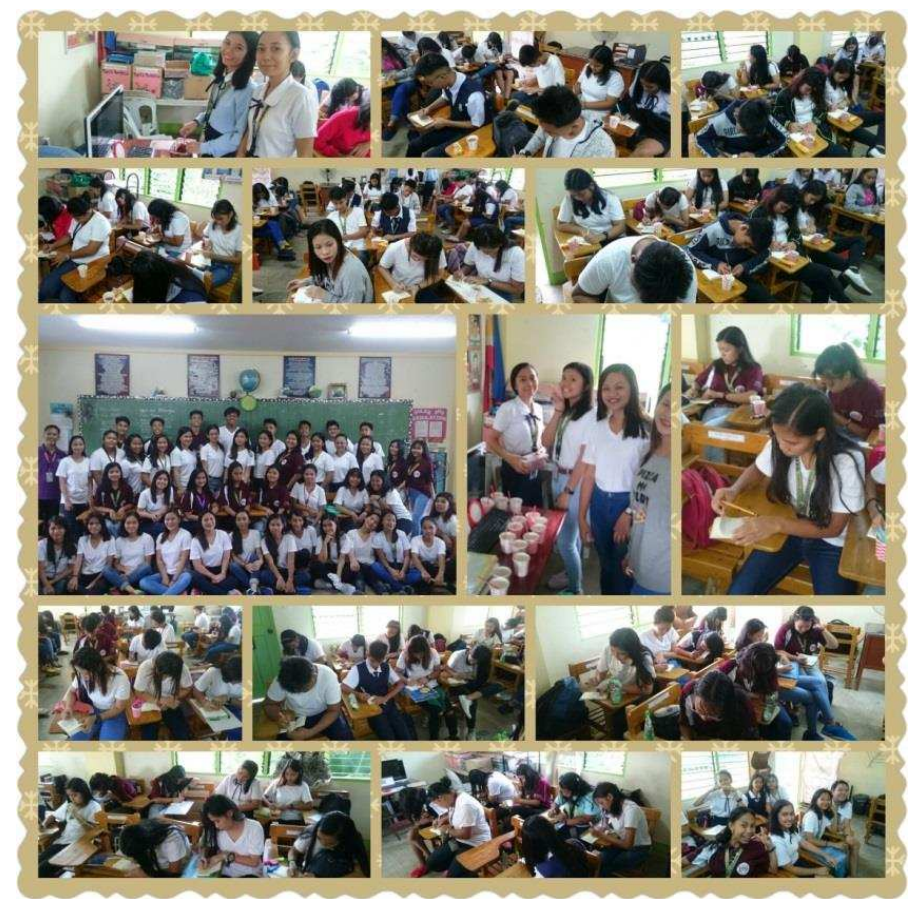

Fig. 1. Grade 11 Vibrant classroom symposia, s.y. 2019-2020, $2^{\text {nd }}$ semester

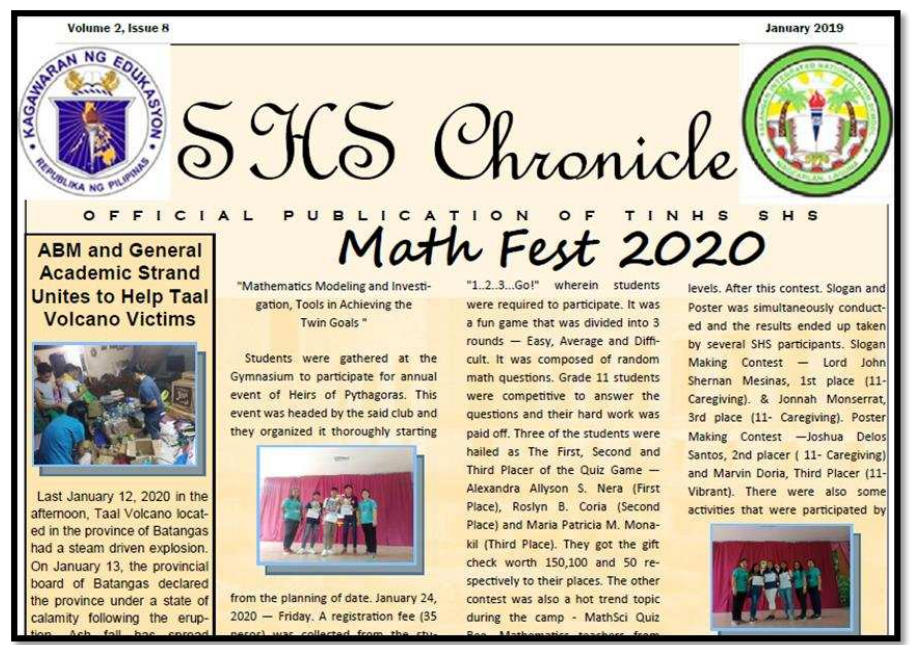

Fig. 2. Grade 11 Vibrant ABM and General Academic Strand reached out to Taal Volcano eruption victims 
When Taal Volcano erupted last January 12, 2020, the learners of Grade 11 Vibrant decided to have their weekly sinking fund be used in reaching-out to the victims residing in Batangas Province. While out of school because of declaration of no-class, they managed to buy goods for the affected families. The news of their calamity response was broadcasted through the monthly Senior High School (SHS) journal of Talangan Integrated National High School (shown above).

This is the reason why the researcher decided to investigate on the role of learners' profile and the symposia done to the calamity response level of the SHS learners. Do sex, family income status and academic performance affect the level of calamity response? Was the awareness created by the symposia related to the calamity response level of the students?

\subsection{Theoretical Framework}

Thorndikes stimulus-response model states that an individual elicits certain response when a stimulus occurs or is being experienced. A puppy who is being bought with a food after the ringing of the bell is salivating, or is generating saliva from his mouth. This activity was done over-and-over again even without the food being given after the ringing of the bell, giving the concept of stimulus-response model.

Learners have also their response routine when calamity hits people's lives. They have a coordinated activity that is already inept to them because it was built through certain nurturing, teaching or valuing. Therefore, Thorndikes model will help analyze the result that would be made out of the result in this study.

\subsection{Conceptual Framework}

The Figure 3 on the next page shows the framework by which this study operates. The input contains the learners' profile, namely, sex, family economic status, and academic performance. The process contains the level of learners' application of the things they are learning the series of symposia done inside the classroom. While the output is composed of the calamity response level of the learners, namely, reaching out, continuous study, and maximizing time. The three calamities that happened during the second semester of s.y. 2019-2020 became the scenario in which this study was suited for investigation.

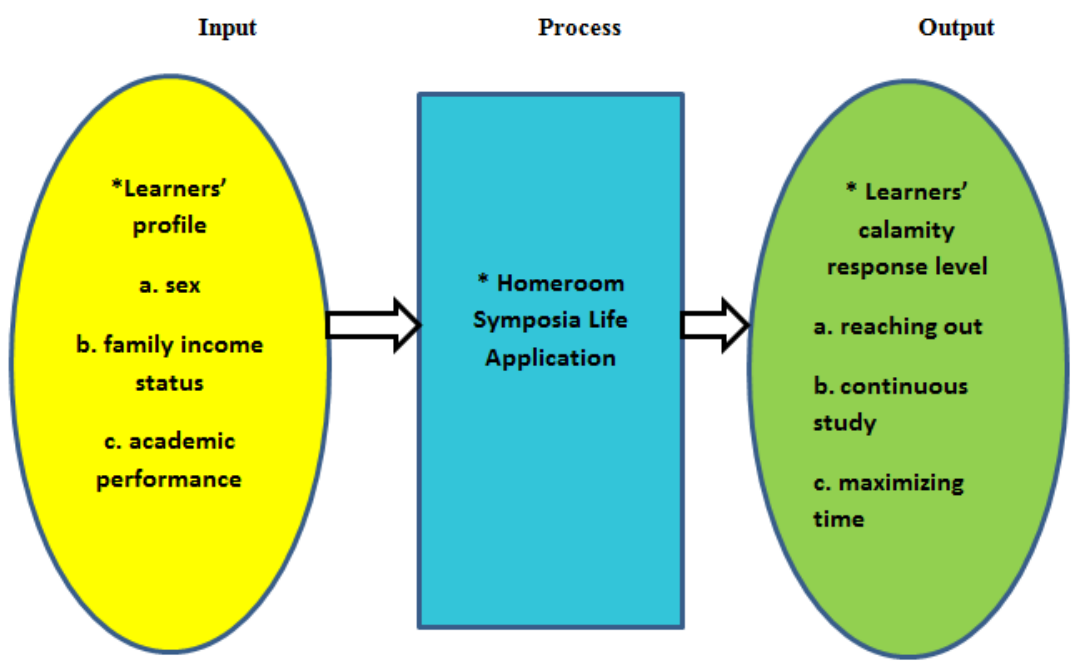

Fig. 3. Paradigm 


\subsection{Objectives of the Study}

This research aims for the following:

1. Find out the significance of the series of homeroom symposium to the lives of Senior High School (SHS) learners;

2. Determine the readiness of SHS learners in reaching out to needy people, study lessons continually, and maximize time in developing potentials during times of calamity and class suspension; and

3. Promote homeroom symposium as one way of molding learners' character which would make them ready in facing various trials outside classroom setting and into the real world.

\subsection{Statement of the Problem}

This study aimed at determining the relationship of the classroom symposia conducted by the adviser/researcher to the response level of learners in the midst of natural calamities and worldwide pandemic. Specifically, it sought to answer the following questions:

- What the is profile of learners in terms of the following:

- sex;

- family income status; and

- academic performance;

- What is the mean level of life's application of the learners with regards to the lesson they learned in the series of symposia?

- What is the mean level of calamity response of the learners in terms of the following:

- reaching out;

- continuous study; and

- maximizing time;

- Is there a significant difference in the calamity response level of learners when checked across sex, family income status, and academic performance?

- Is there a significant relationship between the learners' application of lessons from the homeroom symposia and their calamity response level?

\subsection{Hypotheses}

The following hypotheses were laid down here as the study was on-going:

1. $\mathrm{H}_{0}$ : There is no significant difference in the calamity response level of learners when checked across sex, family income status, and academic performance.

$\mathrm{H}_{\mathrm{a}}$ : There is a significant difference in the calamity response level of learners when checked across sex, family income status, and academic performance.

2. $\mathrm{H}_{0}$ : There is no significant relationship between the learners' application of lessons from the homeroom symposia and their calamity response level.

$\mathrm{H}_{0}$ : There is a significant relationship between the learners' application of lessons from the homeroom symposia and their calamity response level.

\subsection{Significance of the Study}

This study would benefit different groups of people. 
- SHS learners could be led to become better workforce in the community not only during times of calamity but on ordinary days as well.

- Teachers can design their homeroom guidance program in the light of the result that can be made in this study. This would aid everyday meetings and would cater into having individual educational planning that highlights learners' needs, progress and achievement, not only academically but also for the total well-being of each learner.

- Schools can have less stress in guiding learners to know their special place in the lives of other people.

- Community now and beyond would be a better place to live in with responsible citizens.

\subsection{Scope and Limitation}

This study was conducted in the context of learners under the academic track. The homeroom guidance program which was being tested here (homeroom symposia) may or may not be applicable for techvoc learners. Though the symposia were done for the entire school year, only the 4 symposia for the $2^{\text {nd }}$ semester became the basis for gathering data. The profile of the leaners which was tested against calamity response were sex, family income status, and academic performance which came from the general average for the entire s.y. 2019-2020. Also, the calamities being mentioned here which was the scenario experienced by the respondents are limited to typhoon, volcanic eruption and worldwide pandemic.

\section{Review of Related Studies and Literature}

This portion of the study attempts to relate previous studies and literature to the present one. The ideas and findings would aid the author in understanding the concepts behind the variables included in this investigation.

\subsection{Sex}

The first of the three profiles under investigation that may or may not affect other variables is sex. In this context, it is understood that that there two - male and female. Sex is distinguished from gender, in that, sex pertains to biological status at birth, while gender refers to the preference of the person on the role and standing. The Department for Education Employment in Great Britain (2000) in their "Sex and Relationship Guidance" book identify three main elements in which male and female can be contrasted or compared: (1) attitudes and values, (2) personal and social skills, and (3) knowledge and understanding. In this study, two sex groups were contrasted on their choice for track, in which, more female learners are choosing academic track than male learners.

\subsection{Family Economic Status}

How is it important to measure family economic status? According to Yadollahi and $\mathrm{Hj}$ Paim (2010), having the data about family economic status in a locality or specified place, poverty reduction can be targeted by planning measures that will help people in the community with job opportunities that will suit their capability.

In different aspects like patience, altruism, risk-seeking attitude and intelligence quotient (IQ), research shows that family economic status is significantly related to them. This is true in the work of Deckers, Falk, Kosse and Schildberg-Hörisch (2015). Would this be also true when family economic status will be checked against calamity response level?

If high level family economic status is related to high level of patience, altruism and IQ, low family economic status was found to produce a likelihood of children being obese, having impaired social and 
emotional skills, and even poor language acquisition. Donkin (2014) in his study found out that this is happening. Would low family economic status affect reaching out to needy people, continuing to study at home during calamity, and maximizing time to develop potentials?

\subsection{Academic Performance}

Haahr (2005), in explaining student performance as evidenced from the international PISA, TIMSS and PIRLS surveys, said that a range of assessment methods can be used in order to assess students' academic progress: Standardized tests, the assessment of student portfolios, judgmental ratings carried out by teachers, regular teacher-developed tests and assessments of student assignments, projects, and homework.

In a synthesis relating to achievement, Hattie (2009) said, "It is students themselves, in the end, not teachers, who decide what students will learn. Thus we must attend to what students are thinking, what their goals are, and why they would want to engage in learning what is offered in schools." In a study made by Katsikas (2010), the academic and social profiles of 867 students, studying in a university of Economic and Social Studies, are analysed by means of Ordinary Least Squares and Quantile Regression Methods. Study showed that social profile, specifically, being a working student, does not significantly affect academic performance. In this study, would calamity response level have significant difference when checked across different academic performance ranges?

\subsection{Homeroom Symposium}

Though homeroom symposium is not directly mentioned by Spiteri (2007), findings in his study suggest such interaction in classrooms so that learners can have their interest and needs being given attention or addressed when there is symposium in which they can directly interact with attendees and facilitator.

Maaske (1994) mentioned that many years ago, symposium was only done in tertiary where there is academic freedom and competencies to be attained can deviated from what is expected as long as the minimum requirement is attained. In his writings, he recommended that symposium in secondary schools be given trial because learners nowadays have multifaceted concerns. Symposium can be done not only for the group of learners in academic setting but also in the context of clubs and organization, parent-teacher meetings or gatherings, and even community-school partnership. This present study agrees with Maaske in exploring the power of symposium in transforming classroom setting from traditional meeting to wholesome in-depth discussion and interaction.

\subsection{Calamity Response}

Mamogale (2011) investigated on the level of awareness of teachers and learners in the aspect of calamity response. It turned out that learners have higher level of knowledge and awareness in terms of calamity response. This can be attributed to the fact that young minds tend to absorb more of the calamity preparedness being given by the institution. This seem to contradict the findings in the study made by Davis, Weber Schulenberg and Green (2019), in which they stated that learners in general have little concern about the occurrence of disasters and therefore have low motivation in facing calamity and its effect. Mutch (2014) recommended that the learners be involved in the planning and implementation of calamity response and preparedness so that they may appreciate being part of the process, and not just waiting on what they can do to alleviate effects of calamity. One way to prepare learners so that they will have appropriate calamity response and preparedness is through homeroom symposium that will cater not just awareness of disasters but values formation like reaching out to affected people. 


\subsection{Reaching Out}

Although Nouwen's writing (1986) focused on self-inflicted struggles, his notion about reaching out is applicable in being of help to others during time of calamity. He mentioned that the more we understand struggling situations, the more we are soak ourselves to a prayerful and genuine live that makes us sensitive for people's needs. During time of calamity when learners need to stay home, their concern for other people is tested and it can be shown in many ways like donating, praying for the people around, spreading encouragements through social media and other ways of alleviating pain.

\subsection{Continuous Study}

The Fifth World Conference on Educational Sciences (2013) mentioned the benefits of continuing education: skills development, academic advancement, and personal growth. Though this is not in the context of staying at home during calamity and having personal study to provide mind nurturing, the benefits also apply to such situation. When learners continue to study although school days are suspended during calamities, they are also having continuous assessment unknowingly. Continuous assessment, according to Ramon-Muñoz (2015) can help improve academic performance because it reveals weakness to the learners that he can focus on improving.

\subsection{Maximizing Time}

Kaplan and Pierre (n.d.) had a concept of reward system for a person not to waste time in improving himself. Though the context of their reward system is on the robotics and improving works, this also applies to the present study of developing full potential instead of being idle at home when calamity strikes. Teenagers should wisely use their time and treasure their teenage years of exploration and gaining knowledge and wisdom. Teenagers would be motivated to develop their full potential if they will teach the proper time management. Wong (2020) mentioned that everyone of us were given same 24 hour that we can make use of in a day. All those who have been in the hall of fame were not given more change than we have. Therefore, it is just a matter on how we make use of the time given to us to discover our full potential.

\section{RESEARCH DESIGN AND METHODOLOGY}

This part of the study provides in detail the design and methodology implemented in order to come up with the conclusion necessary in answering the questions posed at the beginning of the exploration.

\subsection{Research Design}

This study made use of quantitative approach in doing research. Creswell (2003) distinguished this approach as a design that "collects data on predetermined instruments that yield statistical data." Also, it is a "positivist claim for developing knowledge". Positivist in this context means that the "social world is patterned and has order." The concept of this study revolves around that concept in which the research would like to explore the predetermined patterned that governs the nature of calamity response of learners, and statistically, established the connection and causality among variables.

\subsection{Sampling}

The researcher made use of purposive sampling in considering who would be the respondents for this 
study. Since the homeroom symposia were conducted with Grade 11 Vibrant composed of Accountancy, Business and Management (ABM) and General Academic Strand (GAS) learners, they were the ones who became the subjects and respondents for this study. The table that follows shows the sample for this paper.

Table 2. The respondents for this study

\begin{tabular}{|c|c|c|c|c|c|c|}
\hline \multirow{2}{*}{ Academic Track } & \multicolumn{3}{|c|}{ Enrollees } & \multicolumn{2}{c|}{ Frequency of Available Respondents } \\
\cline { 2 - 7 } & Male & Female & Combined & Male & Female & Combined \\
\hline ABM & 2 & 15 & 17 & 2 & 13 & 15 \\
\hline GAS & 7 & 16 & 23 & 6 & 11 & 17 \\
\hline Total & $\mathbf{9}$ & $\mathbf{3 1}$ & $\mathbf{4 0}$ & $\mathbf{8}$ & $\mathbf{2 4}$ & $\mathbf{3 2}$ \\
\hline
\end{tabular}

There were 40 enrolees for Grade 11 Vibrant for this s.y. 2019-2020, second semester. While at home for Enhanced Community Quarantine, learners stayed at home and they were communicated with the researcher through online social media. Out of 40 enrolees, 32 were able to respond to the questionnaire forwarded to them. This frequency already depicts a normal distribution which would already provide a comprehensive result when statistics was applied.

\subsection{Data Gathering Instrument}

The researcher made use of close-ended questionnaire that elicits the following data (Appendix A):

- Family Income Status

- Homeroom Symposia Life Application Level

- Calamity Response Level

- Reaching Out

- Continuous Study

- Maximizing Time

The gender and academic performance was already part of the adviser's/researcher's record so it was not anymore asked in the questionnaire. For the academic performance, the general average for the entire s.y. 2019-2020 was used. For family income status (mother and father already combined), learners were given three choices:

- Php 10,000 and below

- 10,001 to 20,000

- 20,001 to 30,000

For the homeroom symposia life application level and calamity response level, the following LikertScale system was used:

Table 3. Indicators' rating and interpretation

$\begin{array}{cccc}\text { Rating } & \text { Interpretation } & \begin{array}{c}\text { Statistical } \\ \text { Range }\end{array} & \begin{array}{c}\text { Interpretation } \\ 5\end{array} \\ 4 & \text { Very Highly Characterizes Me } & 4.21-5.00 & \text { Very High Level } \\ 3 & \text { Highly Characterizes Me } & 3.41-4.20 & \text { High Level } \\ 2 & \text { Somehow Characterizes Me } & 2.61-3.40 & \text { Moderate Level } \\ 1 & \text { Seldom Characterizes Me } & 1.81-2.60 & \text { Low Level } \\ & \text { Does Not at All Characterize Me } & 1.00-1.80 & \text { Very Low Level }\end{array}$

\subsection{Data Gathering Procedure}

The figure that follows shows the step-step-step procedure applied by the researcher in order to obtain data needed to answer the questions posed at the beginning of the study. 


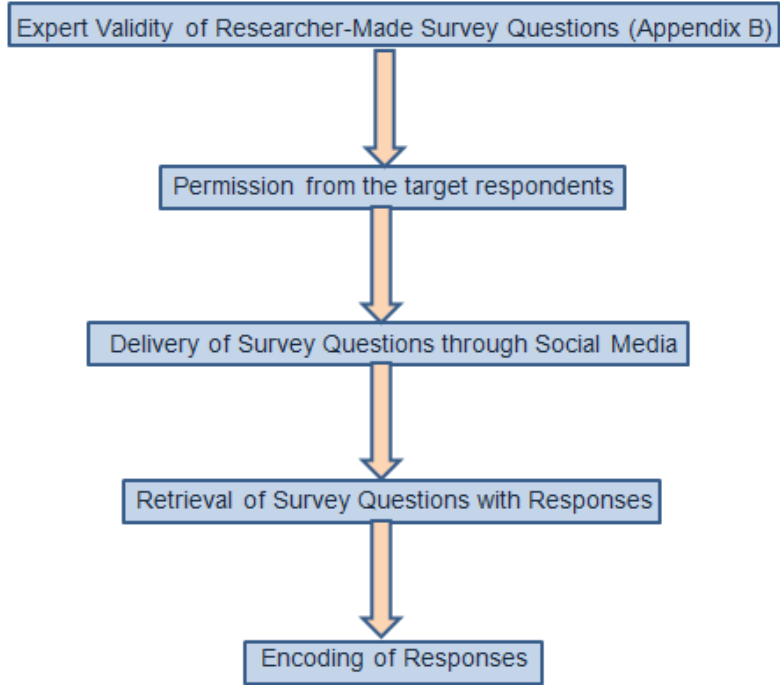

Fig. 4. Flowchart of data gathering procedure

First, expert validity of survey questions made was sought through online checking from someone with terminal degree status (Appendix B). This was done through social media also because of Enhanced Community Quarantine. Second, permission from target respondents was secured through invitation to answer the survey questions forwarded to them. Third, delivery of survey questions for each target respondents was delivery through private message. Fourth, retrieval of responses was done, and last, they were encoded, ready for statistical treatment.

\subsection{Ethical Considerations}

Four things were put into consideration to make sure that this study complies with ethical standard: - Informed consent - The purpose of the study were brought clearly into the target respondents' consent. Answering the survey questions were given as an invitation and not mandatory.

- Respondents' freedom for cooperation - The learners' were given the choice to be or not to be part of the study. Invitation was sent through social media and those who decided to be part of the study gave private message to the researcher.

- Respondent's identity protection - It was known to the respondents that their identity will not be divulged, and the responses were only to be used for the purpose of the study.

- Disclosure of salient findings to the respondents - After the processing of data statistically and having the result analyzed and interpreted, the important findings was shared to the respondents.

\subsection{Statistical Tools}

The following statistical tools were used to answer the questions posed at the beginning of the study:

- for Statement of the Problem \#1 (SOP \#1) - frequency

- for SOP \#s 2 and 3 - mean and standard deviation

- for SOP \#4 - analysis of variance (ANOVA)

- for SOP \#5 - Pearson-R 


\section{Presentation, Analysis and Interpretation of Data}

This part of the study features the presentation, interpretation and analysis of data obtained from the conduct of homeroom symposia and the responses to the questionnaire distributed to the learners.

4.1. Sex

The figure that follows depicts the composition of sex of the 32 respondents in this study. It can be seen that $25 \%$ of the respondents, that is, 8 learners are male, while $75 \%$ or 24 learners are female. This is not anymore surprising because the enrollees for the academic track in the subject school were majority female. Most male learners are entering technical vocational track, specifically Automotive and ICT (Information and Computer Technology).

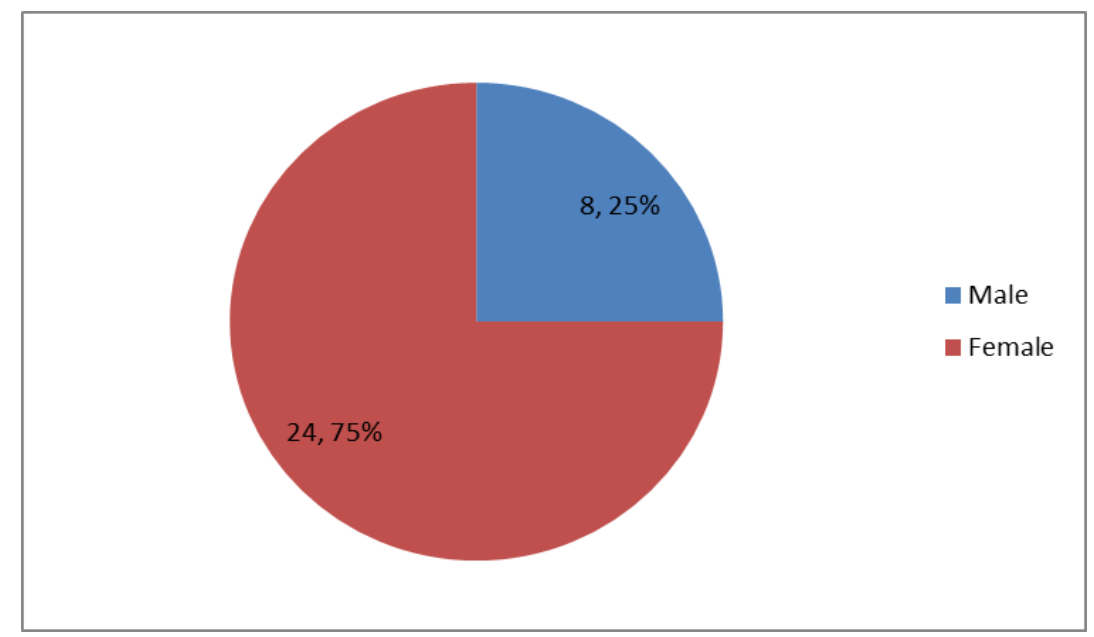

Fig. 5. Distribution of sex of respondents

\subsection{Family Economic Status}

The figure that follows displays the composition of the family economic status of the respondents. The below average group, that is, receiving P10,000 and below combined monthly income of mother and father, comprised $60 \%$ of the respondents, or 19 families out of 32 . The average group (10,001 to 20,000) comprised $34 \%$ of the respondents, or 11 families out of 32 . On the other hand, the above average group (20,001 to 30,000) comprised $6 \%$ of the respondents, or 2 families out of 32. Most families in Nagcarlan earn their living by packing and repacking goods like biscuits and sweets. Only few have their business or are working in far cities as laborer in factory, company or establishments. Some are farmers small business owners, employee in government or private agencies, or having contractual works as carpenter, mason, or skilled and unskilled works. 


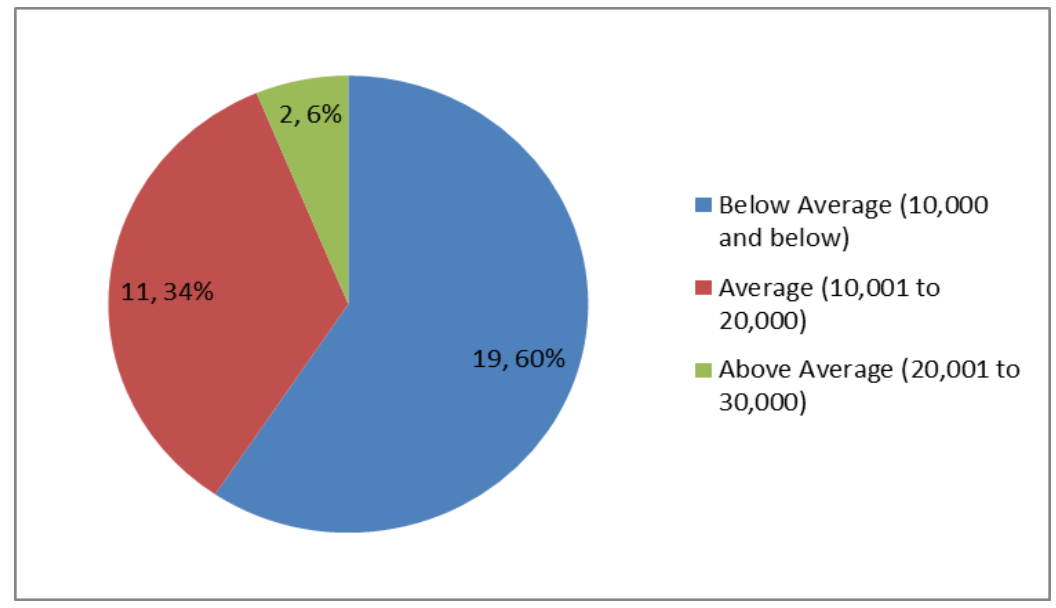

Fig. 6. Distribution of family economic status of the respondents

\subsection{Academic Performance}

The figure that follows highlights the composition of respondents in terms of their academic performance. As mentioned earlier, the academic performance was based on the general average grade of the learners for the entire s.y. 2019-2020. It can be seen that $10 \%$ of the respondents, or 3 out of 32 belong to the developing category, or 80 to 84 general average grades. Thirty-four percent of the learners, of 11 out of 32 belong to the approaching proficiency category, or 85 to $89 \%$ general average grade. On the other hand, $56 \%$ of the respondents, or 18 out of 32 belong to the proficient category, or 90 to 94 general average grades. It is interesting to note that majority of the learners under the academic track has a proficient level, knowing that those who enroll in this tract are ready in terms of academic aspect. They perform well, they conscientiously comply to requirements, they do their homework ahead of time, they help and encourage each other.

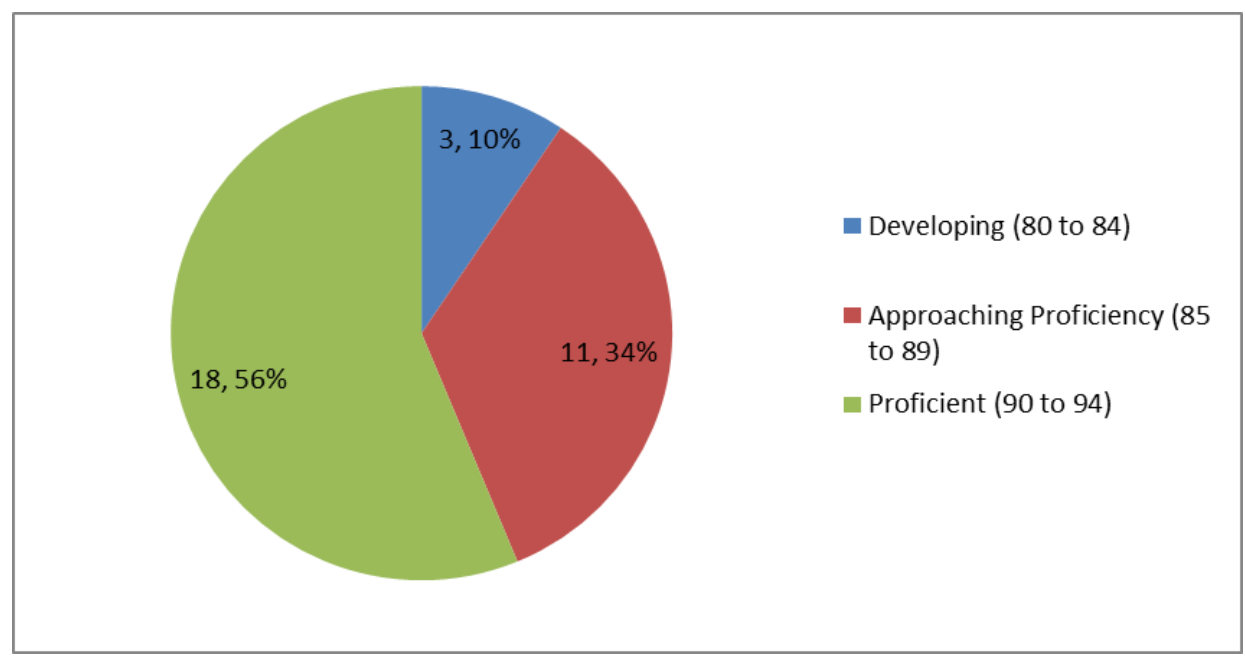

Fig. 7. Distribution of academic performance of the respondents 


\subsection{Homeroom Symposia Life Application}

Table 4. Homeroom symposia life application level of the respondents

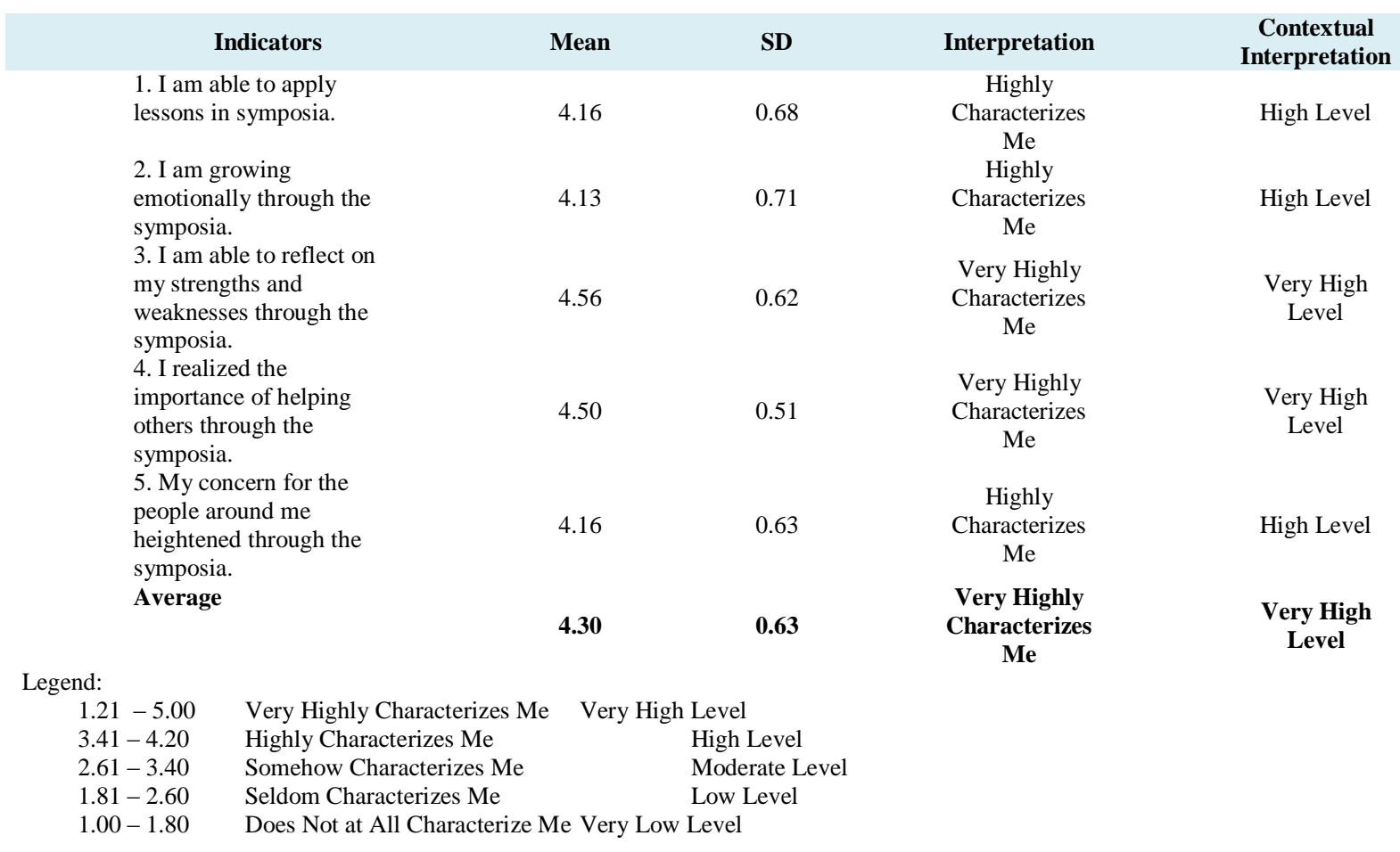

The table above depicts the homeroom symposia life application level of the learners, as they themselves perceive it. Item no. 1 which is the application of the lessons was deemed at high level. Item no. 2, emotional growth, was also set at high level. Item no. 3, reflection on strengths and weaknesses, landed on very high level. Realization of importance of helping others which is item no. 4 was seen to be at very high level. And for item no. 5, concern for the people around, the high level was attained. Overall, the homeroom symposia life application of the learners reached very high level. The learners were able to apply in their lives the lesson they are learning in the homeroom symposium being conducted once a month by their adviser.

\subsection{Reaching Out}

Table 5. Calamity response level in terms of reaching out to others

\begin{tabular}{|lccc}
\multicolumn{1}{c}{ Indicators } & Mean & SD & $\begin{array}{c}\text { Contextual } \\
\text { Interpretation }\end{array}$ \\
$\begin{array}{l}\text { 1. In the midst of } \\
\text { calamities, I sacrifice some } \\
\text { of my finances for other } \\
\text { people. }\end{array}$ & 3.19 & 0.86 & $\begin{array}{c}\text { Somehow } \\
\text { Characterizes } \\
\text { 2. During calamities, I }\end{array}$ \\
$\begin{array}{l}\text { used to find ways to } \\
\text { encourage others. }\end{array}$ & 3.84 & 0.77 & $\begin{array}{c}\text { Moderate } \\
\text { Level } \\
\text { 3. When calamities strike, }\end{array}$ \\
$\begin{array}{l}\text { I update myself with } \\
\text { things happening to other }\end{array}$ & 4.38 & 0.75 & $\begin{array}{c}\text { Me } \\
\text { Very Highly } \\
\text { Characterizes } \\
\text { Me }\end{array}$
\end{tabular}


people through social

media and television news.

4. When there is

opportunity to help, I

4.09

0.78

never waste time to extend$$
0.78
$$

help.

5. Calamities give me

opportunity to share

blessings and provide for

the needy.

Average

$$
\begin{gathered}
\text { Highly } \\
\text { Characterizes } \\
\text { Me } \\
\text { Highly } \\
\text { Characterizes } \\
\text { Me } \\
\text { Highly }
\end{gathered}
$$

Characterizes High Level
High Level

High Level
Legend:

$$
\begin{aligned}
& 1.21-5.00 \\
& 3.41-4.20 \\
& 2.61-3.40 \\
& 1.81-2.60 \\
& 1.00-1.80
\end{aligned}
$$

\author{
Very Highly Characterizes Me \\ Highly Characterizes Me \\ Somehow Characterizes Me \\ Seldom Characterizes Me \\ Does Not at All Characterize Me
}

\author{
Very High Level \\ High Level \\ Moderate Level \\ Low Level

\begin{tabular}{|c|c|c|c|c|c|}
\hline & Indicators & Mean & SD & Interpretation & $\begin{array}{c}\text { Contextual } \\
\text { Interpretation }\end{array}$ \\
\hline & $\begin{array}{l}\text { 1. When calamities strike, } \\
\text { I am saddened by the fact } \\
\text { that I can't go to school. }\end{array}$ & 3.59 & 0.84 & $\begin{array}{c}\text { Highly } \\
\text { Characterizes } \\
\mathrm{Me}\end{array}$ & High Level \\
\hline & $\begin{array}{l}\text { 2. I read lessons in } \\
\text { advance when I need to } \\
\text { stay home during } \\
\text { calamities. }\end{array}$ & 2.97 & 0.74 & $\begin{array}{c}\text { Somehow } \\
\text { Characterizes } \\
\text { Me }\end{array}$ & $\begin{array}{c}\text { Moderate } \\
\text { Level }\end{array}$ \\
\hline & $\begin{array}{l}\text { 3. I review my notes or } \\
\text { practice applying lessons I } \\
\text { learned in school. }\end{array}$ & 2.97 & 0.82 & $\begin{array}{c}\text { Somehow } \\
\text { Characterizes } \\
\text { Me }\end{array}$ & $\begin{array}{c}\text { Moderate } \\
\text { Level }\end{array}$ \\
\hline & $\begin{array}{l}\text { 4. I take time to research } \\
\text { more on topics studied in } \\
\text { classroom. }\end{array}$ & 2.84 & 0.95 & $\begin{array}{c}\text { Somehow } \\
\text { Characterizes } \\
\text { Me }\end{array}$ & $\begin{array}{c}\text { Moderate } \\
\text { Level }\end{array}$ \\
\hline & $\begin{array}{l}\text { 5. I communicate with } \\
\text { classmates and/or teachers } \\
\text { to keep me going in school } \\
\text { projects or scheduled } \\
\text { lessons. }\end{array}$ & 3.47 & 1.22 & $\begin{array}{l}\text { Highly } \\
\text { Characterizes } \\
\text { Me }\end{array}$ & High Level \\
\hline & Average & 3.17 & 0.91 & $\begin{array}{c}\text { Somehow } \\
\text { Characterizes } \\
\text { Me }\end{array}$ & $\begin{array}{c}\text { Moderate } \\
\text { Level }\end{array}$ \\
\hline $\begin{array}{r}1.21 \\
3.41\end{array}$ & $\begin{array}{l}-5.00 \\
-4.20\end{array}$ & $\begin{array}{l}\text { icterizes Me } \\
\text { es Me }\end{array}$ & & evel & \\
\hline
\end{tabular} \\ Very Low Level
}

The table above depicts the calamity response level in terms of reaching out to others, as the learners perceive it. Item no. 1 which is sacrificing finances was deemed at moderate level. Item no. 2, encouraging others, was set at high level. Item no. 3, getting updated with current news, landed on very high level. Never wasting time to extend help which is item no. 4 was seen to be at high level. And for item no. 5, sharing blessings, the high level was attained. Overall, the calamity response level in terms of reaching out to other people reached very high level. The learners have a high concern with the people around them, especially those who are hurting, when calamity strikes either to their community or to other places near and far.

\subsection{Continuous Study}

Table 6. Calamity response level in terms of continuous study while at home 


$\begin{array}{lll}2.61-3.40 & \text { Somehow Characterizes Me } & \text { Moderate Level } \\ 1.81-2.60 & \text { Seldom Characterizes Me } & \text { Low Level } \\ 1.00-1.80 & \text { Does Not at All Characterize Me Very Low Level }\end{array}$

The table above depicts the calamity response level in terms of continuous study while at home, as the learners perceive it. Item no. 1 which is the sadness of not going to school was deemed at high level. Item no. 2, reading lessons in advance, was set at moderate level. Item no. 3, reviewing notes, landed on moderate level. Taking time to research which is item no. 4 was seen to be at moderate level. And for item no. 5, communication with classmates and teachers, the high level was attained. Overall, the calamity response level in terms of continuous study reached moderate level. The learners were torn between going to school and staying at home. Some are continuing to study at home while others are taking advantage of rest time.

\subsection{Maximizing Time}

Table 7. Calamity response level in terms of maximizing time to do productive tasks

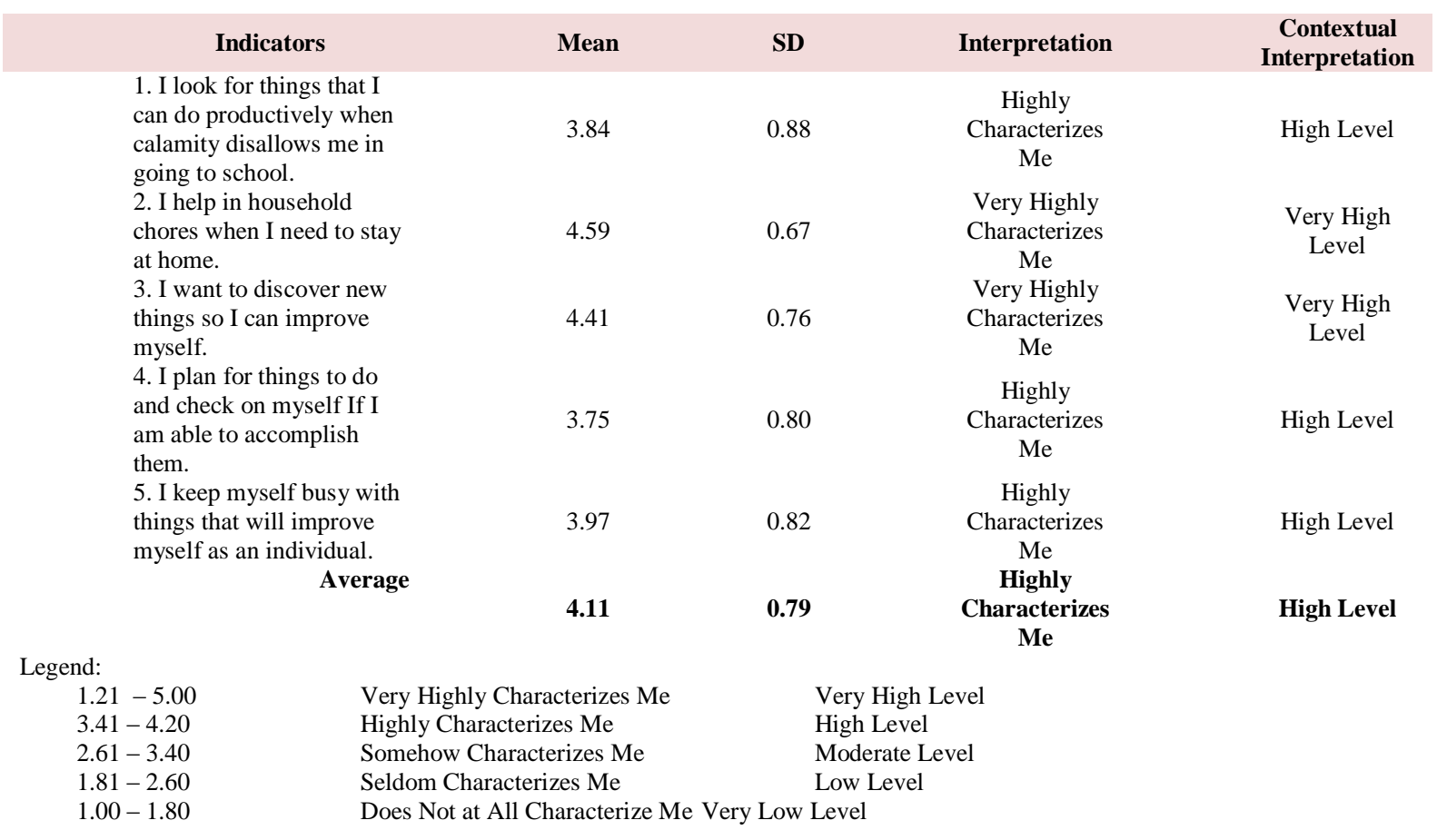

The table above depicts the calamity response level in terms of maximizing time to do productive tasks, as learners perceive it. Item no. 1 looking for things to do at home was deemed at high level. Item no. 2 , doing household chores, was set at very high level. Item no. 3, discovering new things, landed on very high level. Planning for things to do and evaluating which is item no. 4 was seen to be at high level. And for item no. 5, keeping oneself busy, the high level was attained. Overall, the calamity response level in terms of maximizing time reached high level. The learners were making their time worthwhile to make themselves improve as an individual when there were calamities and they could not go to school. 


\subsection{Difference in Calamity Response Level across Sex}

The table below lays down the results of ANOVA tool application for the difference of mean level in calamity response level in three indicators across the difference sex groups. Male group has lower reaching out level, higher continuous study level, and higher maximizing time level compared to the female group. All of these differences were seen to be of none significance using ANOVA. It was attested by the lower F-values compared to the critical value, and was supported by the P-values which are all greater than the alpha value. With $95 \%$ level of confidence, it can be said that sex has nothing to do with the calamity response level of Senior High School learners. Whether the learner is male or female, the calamity response level does not have an attribution from or is not affected by sex. Wong (2020) in his book celebrates the strengths of both male and female - Albert Einstein and Mother Teresa, Issac Newton and Eleanor Roosevelt. Calamity response cannot be associated for male only or for female only. Both can excel on this aspect, depending on their physical, mental and emotional preparation.

Table 8. ANOVA result of calamity response level across sex groups

\begin{tabular}{|c|c|c|c|c|c|c|c|c|c|c|c|c|c|c|c|}
\hline \multirow{2}{*}{ Sex } & \multicolumn{3}{|c|}{ Mean } & \multicolumn{3}{|c|}{ F-value } & \multicolumn{3}{|c|}{ F-crit } & \multicolumn{3}{|c|}{ P-value } & \multicolumn{3}{|c|}{ Decision } \\
\hline & $\mathrm{RO}$ & $\mathrm{CS}$ & MT & $\mathrm{RO}$ & $\mathrm{CS}$ & MT & $\mathrm{RO}$ & $\mathrm{CS}$ & MT & $\mathrm{RO}$ & $\mathrm{CS}$ & MT & $\mathrm{RO}$ & $\mathrm{CS}$ & MT \\
\hline Male & 3.78 & 3.28 & 4.15 & 0.07 & 0.28 & 0.03 & & 4.17 & & 0.80 & 0.60 & 0.85 & $\mathrm{~N}$ & $\mathrm{~N}$ & $\mathrm{~N}$ \\
\hline Female & 3.83 & 3.13 & 4.10 & & & & & & & & & & $\mathrm{~N}$ & $\mathrm{~N}$ & $\mathrm{~N}$ \\
\hline
\end{tabular}

alpha $=0.05$

Legend:

$$
\begin{aligned}
& \text { RO - Reaching Out } \\
& \text { CS - Continuous Study } \\
& \text { MT - Maximizing Time } \\
& \text { N - Not Significant }
\end{aligned}
$$

\subsection{Difference in Calamity Response Level across Family Economic Status}

The table below lays down the results of ANOVA tool application for the difference of mean level in calamity response level in three indicators across the family economic status categories. In terms of reaching out, the average group has the highest mean level while the above average group has the lowest mean level. In terms of continuous study and maximizing time, the above average group has the highest mean level while the average group has the lowest mean level. Only reaching was seen to have significant difference across family economic status category using ANOVA. It was attested by the higher F-value compared to the critical value, and was supported by the P-values which is lower than the alpha value. With $95 \%$ level of confidence, it can be said that family economic status has something to do with the calamity response level of Senior High School learners. Those with average family income reach out conscientiously to needy persons during calamity distress. They may not have all the means but they understand the situation of those experiencing lack in finance and primary needs to survive. This is in contrast with the findings of the work made by Donkin (2014). It turned out that those with lower family income status have higher social and emotional skills.

Table 9. ANOVA result of calamity response level across family economic status

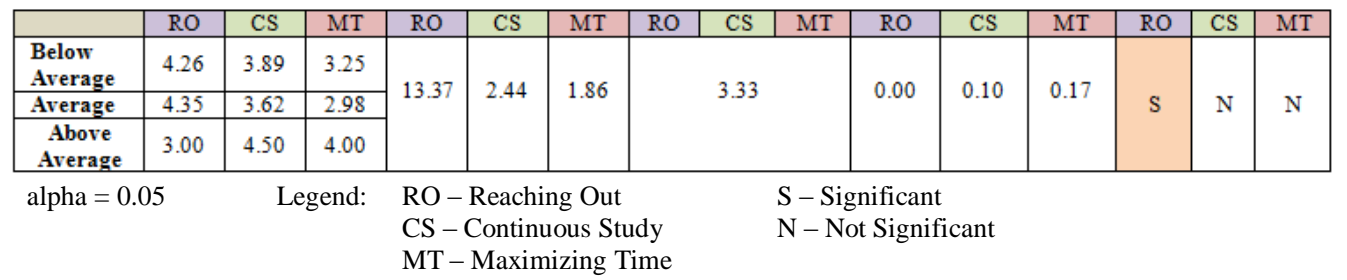




\subsection{Difference in Calamity Response Level across Academic Performance}

The table below lays down the results of ANOVA tool application for the difference of mean level in calamity response level in three indicators across the academic performance categories. For the three indicators of calamity response, the proficient has the highest mean level while the developing has the lowest mean level. Nevertheless, these differences were seen to be of none significance using ANOVA. It was attested by the lower F-values compared to the critical value, and was supported by the P-values which are all greater than the alpha value. With $95 \%$ level of confidence, it can be said that academic performance has nothing to do with the calamity response level of Senior High School learners. Whether the learner is developing, approaching proficiency or proficient in academic performance, the calamity response level does not have an attribution from or is not affected by academic performance. This is in consonance with the findings of the study made by Katsikas (2010). In his study, social profile has nothing to do with academic performance. On this present study, it turned out however is the academic performance of the learners, they tend to reach out for people in need in times of crisis, they continue to study, and they maximize time in developing their full potential.

Table 10. ANOVAresult of calamity response level across academic performance

\begin{tabular}{|c|c|c|c|c|c|c|c|c|c|c|c|c|c|c|c|}
\hline \multirow{2}{*}{ Sex } & \multicolumn{3}{|c|}{ Mean } & \multicolumn{3}{|c|}{ F-value } & \multicolumn{3}{|c|}{ F-crit } & \multicolumn{3}{|c|}{ P-value } & \multicolumn{3}{|c|}{ Decision } \\
\hline & RO & $\mathrm{CS}$ & MT & RO & $\mathrm{CS}$ & MT & RO & $\mathrm{CS}$ & MT & RO & $\mathrm{CS}$ & MT & RO & $\mathrm{CS}$ & MT \\
\hline Developing & 4.13 & 3.33 & 2.40 & & & & & & & & & & & & \\
\hline $\begin{array}{l}\text { Approaching } \\
\text { Proficiency }\end{array}$ & 4.27 & 3.73 & 3.36 & 0.50 & 2.00 & 2.93 & & 4.17 & & 0.61 & 0.15 & 0.07 & $\mathrm{~N}$ & $\mathrm{~N}$ & $\mathrm{~N}$ \\
\hline Proficient & 4.34 & 3.96 & 3.18 & & & & & & & & & & & & \\
\hline alpha $=0.05$ & & Leg & & $\begin{array}{l}\mathrm{O}-\mathrm{R} \\
\mathrm{S}-\mathrm{C} \\
\mathrm{T}-\mathrm{I} \\
-\mathrm{No}\end{array}$ & $\begin{array}{l}\text { achin } \\
\text { tinuc } \\
\text { ximi } \\
\text { Signi }\end{array}$ & $\begin{array}{l}\text { Out } \\
\text { s Stu } \\
\text { ng T } \\
\text { ant }\end{array}$ & & & & & & & & & \\
\hline
\end{tabular}

\subsection{Summary of Difference in Calamity Response Level}

The table below shows the summary of ANOVA results in testing the significant difference of in the mean level of calamity response across learners' profile. It can be seen that only family income status has something to do with reaching out. This is shown by the P-value which is lower than that alpha value. Those who have average family income tend to reach out more than those who have low average and above average family income. This can be explained by the fact that they have something to give unlike the below average which has no excess from their everyday needs. At the same time, this average family income group understands the situation of those people in need more than those above average group. The average family income group may have experienced being at a low state in life in which they hardly survive in a day, whereas those above average group seldom experience being in scarcity. In the study made by Deckers, Falk, Kosse and Schildberg-Hörisch (2015), they relate family economic status to patience, altruism and risk-seeking attitude. This study has a different notion from the said study by Deckers et.al. in having a findings that the average family income status has higher level of reaching out to need people than the above average family income status.

Table 11. Summary of ANOVA results

\begin{tabular}{|c|c|c|c|c|c|c|}
\hline \multirow{2}{*}{$\begin{array}{l}\text { Learners'Profile } \\
\text { vs. Calamity } \\
\text { Response }\end{array}$} & \multicolumn{2}{|c|}{ Reaching Out } & \multicolumn{2}{|c|}{ Continuous Study } & \multicolumn{2}{|c|}{ Maximizing Time } \\
\hline & P-value & Decision & P-value & Decision & P-value & Decision \\
\hline Sex & 0.80 & $\mathrm{~N}$ & 0.60 & $\mathrm{~N}$ & 0.85 & $\mathrm{~N}$ \\
\hline $\begin{array}{c}\text { Family Income } \\
\text { Status }\end{array}$ & 0.00 & $\mathrm{~s}$ & 0.10 & $\mathrm{~N}$ & 0.17 & $\mathrm{~N}$ \\
\hline $\begin{array}{c}\text { Academic } \\
\text { Performance }\end{array}$ & 0.61 & $\mathrm{~N}$ & 0.15 & $\mathrm{~N}$ & 0.07 & $\mathrm{~N}$ \\
\hline
\end{tabular}


4.12. Relationship of Homeroom Symposia Life Application and Calamity Response Level

Table 12. Pearson-R result of homeroom symposia application vs calamity response

\begin{tabular}{ccccc}
$\begin{array}{c}\text { Calamity } \\
\text { Response } \\
\text { Reaching } \\
\text { Out } \\
\text { Continuous } \\
\text { Study } \\
\text { Maximizing } \\
\text { Time }\end{array}$ & r-value & r-critical & P-value & 0.413 \\
\hline alpha $=0.05 \quad$ & 0.150 & 0.359 & 0.011 & $\mathrm{~N}$ \\
\hline
\end{tabular}

The table above shows the Pearson- $\mathrm{R}$ results of testing homeroom symposia application against the three indicators of calamity response. Among the three indicators, two showed to have significant relationship with the conduct and application lesson of homeroom symposia: continuous study and maximizing time. The two lessons from among four which was conducted inside the classroom from November 2019 to February 2020 enabled the learners to respond properly during times of calamity. The positive r-values indicate that if the perception and application of lessons in homeroom symposia is high, then the calamity response in terms of continuous study and maximizing time will also be of high level. Statistically, this is shown by higher computed r-values compared to critical value, and is supported by P-values values being lower than the alpha value. With $95 \%$ level of significance, it can be said that the conduct and application of lessons in homeroom symposia has significant relation to the calamity response level of Senior High School learners. This does not mean causality, in which, when the conduct of homeroom symposium was conducted and the learners' were able to apply the concepts learned, the continuous study and maximizing time concept of learners follow. It may be that other factors affect both that heighten them at the same time. Enough to say through the result of Pearson-R that when homeroom symposium level of conduct and application was of high level, the calamity response in terms of continuous study of learners at home and maximizing time of doing productive tasks will also be of high level, and the vice versa is also true.

This supports the notion of Maaske (1994) that symposiums should be brought down to classrooms, from the tertiary setting to the secondary setting. Lots of things can be discussed during symposium and the learners would see themselves being involved in the process especially when it is done in homerooms. Nonacademic topics would enlighten learners in the reality of life that would keep them going during times of struggles, pain, sufferings and trials. Homeroom symposium is a unique way of doing homeroom guidance program because it caters to the mind and emotions of the attendee when topics are discussed thoroughly through interactions in question and answer format. Meaningful ideas can be added like having breakfast or snack while doing the symposium. Asking learners to write reflection on a journal would seal their learning and help them apply the lessons they have learned in their own lives. This does not mean setting aside competencies for different subjects because this will be scheduled once a month and would only consume vacant times of the learners, as agreed by the adviser and the learners.

\section{Summary, Findings, Conclusion, Recommendation and Reflection}

This portion of research puts into culmination the study that was conducted, through laying down of summary, significant findings, conclusion, recommendation and reflection of the author.

\subsection{Summary}

The conduct of once a month homeroom symposium as part of the homeroom guidance program of the adviser/researcher to the learners started during the first semester of school year 2019-2020, but it was 
this second semester that the author investigated its relation to the calamity response of Senior High School learners because of the emergence of typhoon, volcanic eruption and pandemic quarantine these past months. This study looked into the following:

- Profile of learners in terms of sex, family economic status and academic performance;

- Homeroom symposia life application level of the learners;

- Calamity response level of learners in terms of reaching out, continuous study and maximizing time;

- Difference of calamity response mean level when checked across sex groups, family economic status category, and academic performance subgroups; and

- Relation of homeroom symposia life application and calamity response mean level of Senior High School learners.

\subsection{Findings}

Gathering, encoding, and statistical treatment of data resulted into the following findings:

- Twenty-five percent of 32 respondents are male, while $75 \%$ are female. Sixty percent of the respondents belong to the below average family monthly income status (Php 10,000 and below) , 34\% belong to average (10,001 to 20,000$)$, while $6 \%$ belong to above average (20,001 to 30,000). For academic performance, $10 \%$ of the respondents are developing (80 to 84 ), $34 \%$ are approaching proficiency (85 to 89 ), while $56 \%$ are proficient (90 to 94$)$.

- The mean level of homeroom symposia application of the respondents is very high (4.30) with standard deviation of 0.63 .

- The mean level of calamity response of learners in terms of reaching out is high $(3.82$, with $s d=0.80)$, in terms of continuous study is moderate ( 3.17 with $\mathrm{sd}=0.91)$, and in terms of maximizing time is high (4.11 with sd $=0.79$ ).

- Using ANOVA, calamity response level in terms of reaching out was found to have significant difference across family income status $(\mathrm{P}$-value $=0.00)$.

- Using Pearson-R, homeroom symposium application level was found to have significant relationship to calamity response in terms of continuous study and maximizing time ( $\mathrm{P}$-values $=0.011$ and 0.010 respectively).

\subsection{Conclusion}

To answer the inferential questions posted at the beginning of the study, the following conclusions are laid down here:

The alternative hypotheses are partially sustained:

- There is a significant difference in calamity response level in terms of reaching out when checked across family income status. Those with average family income status have the highest level of reaching out to needy people, and those with above average family income status have the lowest level of reaching out to people affected by calamity.

- There is a significant relationship between the mean level of learners' application of lessons from homeroom symposia and calamity response of Senior High School learners in terms of continuous study at home and maximizing time to do productive tasks. If the homeroom symposium life application is of high level, the learners' continuous study at home and maximizing time to develop full potential is also heightened.

\subsection{Recommendation}

To make the findings and conclusion in this study of greater use, the following recommendations are given: 
- Classroom advisers should consider homeroom symposium as one way of guiding learners so that they may become productive citizens and at the same time a strong workforce in building the nation especially in reaching out to people not only in times of calamity but as holistic aspect of human behavior.

- School heads should promote the implementation of homeroom guidance program to all teachers under his care, as a precautionary measure in dealing with learners' misbehavior. School learning action cell should create venues to highlight best practices that teachers can adopt to suit learners' diversity, needs and interests.

- District supervisors should lead in creating projects that would encourage teachers to handle effective homeroom guidance programs, leading to learners' utmost performance in school, not only academically but also in extra-curricular aspects of social awareness and interaction.

- Future researchers should investigate more on factors affecting calamity response level of learners, reaching out to people around him, continuous study at home in the midst of calamities, and maximizing time to discover and develop their own potentials. Such factors can be family relationship, peer pressure, and attitude towards education.

\subsection{Reflection}

In the course of this study, the author asked himself if quality time spent in homeroom symposia for his advisory learners became worthwhile in such a way that it prepared them in facing emergent situations in which their sense of being progressive individuals would be tested and measured. Responses of the learners and the conclusion that emanated from processing the data made him overwhelmed and thankful that nothing that was spent with the heart would be wasted.

The learners respond not just because of the stimulus, but also because of how they were trained to value the gift of life. Numbers, data, information, listings and even those things which seemed to be of importance fall out of significance when measured against real life situations and the manner on how learners respond to them. Knowledge is information, while wisdom is the application of it. We provide learners with knowledge, but the more important thing is laying them the guidelines on how they would be able to use knowledge on practical situations. These guidelines cannot be listed on the board. Learners form it in their minds and hearts whenever we make our lives a springboard to them, and whenever we point to them the best model, Jesus Christ. He came to seek and save that which was lost (Luke 19:10). That would be a great wisdom to relate to them that their learning is worthless if they cannot use it to develop their own potential, reach out to people in need and be able to make a difference.

\section{Acknowledgement}

The researcher would like to thank the participation of the Grade 11 Vibrant (ABM and GAS) learners of Talangan Integrated National High School, s.y. 2019-2020, towards the accomplishment of this study. Through their inputs, this study became more meaningful to the author and to their section as well. They are indeed VIBRANT (Very Inspired, Brave, Resilient, And Nourished with Talents).

\section{References}

AHA Centre Disaster Monitoring and Response System (DMRS). (2019). Typhoon Kammuri Philippines Flash Update \#4.

Bennett, Barrie, Carol Rolheiser-Bennett and Laurie Stevahn. (1991). Cooperative Learning: Where Heart Meets Mind. Toronto: Educational Connections.

Creswell, J.W. (2003). Research Design: Qualitative, Quantitative, and Mixed Approaches (2 ${ }^{\text {nd }}$ ed.). Thousand Oaks, CA: Sage.

Davis, Christal N., Marcela C. Weber, Stefan E. Schulenberg and John J. Green. (2019). "University Students' Disaster Preparedness: A Focus Group Study. The Follmer Group, Best Practices in Mental Health, Vol. 15, No. 2

Deckers, Thomas, Armin Falk, Fabian Kosse, and Hannah Schildberg- Hörisch. (2015). "How Does Socio-Economic Status Shape a Child's Personality?" Discussion Paper No. 8977. Institute for the Study of Labor (IZA). P.O. Box 7249, 53072 Bonn, Germany. 
Depart for Education and Employment.. (2000). Sex and Relationship Education Guidance. ISBN 184185144 2, Great Britain

Donkin, Angela. (2014). "Family socio-economic status and young children's outcomes.” Journal of Children's Services

Fifth World Conference on Educational Sciences. (2013). Procedia - Social and Behavioral Sciences 116. pp. 4052 - 4056. Published by Elsevier Ltd. Al

Haahr, J. H., M. E. Hansen, S. T. Jakobsen, and T. K. Nielsen. (2005). Explaining Student Performance Evidence from the international PISA, TIMSS and PIRLS surveys. Danish Technological Institute, November

Hattie, J. (2009). Visible Learning: A Synthesis of Over 800 Meta-Analysis Relating to Achievement. New York: Routledge.

Kaplan, Fr'ed'eric and Pierre-Yves Oudeyer. (n.d.). "Maximizing learning progress: and internal reward system for development." Development Robotics Group. Sony Computer Science Laboratory Paris. 6 rue Amyot, 75005 Paris, France

Katsikas, E. and T. Panagiotidis. (2010). "Status and Academic Performance: an approach of the quality determinants of university studies in Greece." Hellenic Observatory Papers on Greece and Southeast Europe. The Hellenic Observatory, the European Institute.

Maaske, Roben J. (1994). “The Symposium Method in High-School Teaching.” The University Chicago Press, Vol. 57, No. 4. pp. 217-22

Mamogale, Hellen Mamosegare. (2011). Assessing disaster preparedness of learners and educators in Soshanguve Norrh schools. submitted in partial fulfillment of the requirements for the degree Masters in Disaster Management. University of the Free State. Africa.

Mutch, Carol. (2014). "The role of schools in disaster preparedness, response and recovery: What can we learn from the literature?" Pastoral Care in Education. The University of Auckland

Nouwen, Henri. (1986). Reaching Out. Published by Image. ISBN 9780385236829

Ramon-Muñoz, Ramon. (2015). "The evaluation of learning: a case study on continuous assessment and academic achievement." Procedia - Social and Behavioral Sciences 196. pp. 149 - 157. University of Barcelona, Department of Economic History and Institutions, Faculty of Economics and Business, Diagonal, 690, Barcelona 08034, Spain

Spiteri, Damian. (2007). "I Want to Learn", 'The Impact of School Culture on How At-Risk Students Perceive Their Behavior at School.' "Responding to Student Diversity: Teacher Education and Classroom Practice Conference Paper. Government Education Division, Malta.

Wikipedia. (2020). "2020 Taal Volcano Eruption."

Wikipedia. (2020). "Luzon Enhanced Community Quarantine.

Wong, Daniel. (2020). "Forty-five Time Management Tips for Students (Advise from a Lifelong Straight-A Student.” Equipping Students to be Successful and Happy.

Yadollahi, Mehdi and Laily Hj Paim. (2010). "Measurement of Family Economic Status.” Journal of Americal Science. Vol. 6, Issue 11. Department of Resources Management and Consumer Studies, Putra University, Malaysia. 